\title{
A REPORT ON THE ORAL TRADITIONS OF THE NORTH PACIFIC RIM, A PERFORMANCE WORKSHOP
}

(Held at Fort Ross, California, 4-10 November 1997)

Ronelle Alexander, University of California, Berkeley

This workshop, the inaugural event of the newly formed Society of Living Traditions (a California not for profit corporation) and the Program on Tradition and Community (based at UC Berkeley), was intended as a pilot experiment. Workshop participants came not only from different geographic regions (Russia, Siberia, Alaska, California, Scotland and Holland), but also from different strata of life experience. They comprised scholars (each with experience in both field research and academic writing), traditional performers (singers, dancers, storytellers), media artists (film-makers, audio specialists, photographers), educators in local schools, and students (from high school to university level).

Approximately thirty participants met over six days; audio, video and photographic records were made of most of the events. The central locus of the workshop was Stillwater Cove Ranch on the northern California coast, where most participants also lived and took their meals. The village-like setting, with outdoor grounds, separate cottages, and the large central lodge with stone fireplace, created a communal atmosphere highly conducive to creative work and intense discussion. Three shorter sessions of the workshop took place in the museum auditorium of the Fort Ross State Historical Park. At two of these, visiting Russian scholars gave multi-media presentations about their field work with Siberian 
native communities, and at the third, participants watched the film Pomo Shaman. Made by a local film-maker, this 20-minute documentary recorded a re-enactment of a healing session conducted by Essie Parrish, the late spiritual leader of the local Qashaya Pomo native settlement.

The intense cross-cultural discussion which took place during all these meetings, between natives representing the different traditions, and the scholars who study these traditions (themselves representing different countries and disciplinary training), allowed each to reach a new and better understanding of the other's work and viewpoint. Students who took part in these discussions, one of whom aided in translation for the Siberian participants, and another of whom is of mixed native/ western parentage, gained valuable experience and direction for future work.

Additional workshop events took place at the Fort Ross School, the HopKiln Winery in neighboring Healdsburg, and in the outdoor stockade area of the Fort Ross State Historical Park. The latter event, which was open to the general public, began with a traditional blessing offered by three of the children of Essie Parrish, the late spiritual leader of the Gashaya Pomo tribe which originated on the land now occupied by the Fort. These representatives remained in the place of honor throughout the afternoon, during which workshop participants representing the different but related native traditions presented their art. In this outdoor setting representing their historical background, members of the Fort Ross community were able both to interact with Russians, Siberians, Alaskans and other native Californians, and to pay respect to the native Californians whose land this originally was. Members of the local community were invited to 
Stillwater Cove that evening for an informal gathering with workshop participants, at which point the creative energy of the week was at a high pitch.

The several events of the workshop created new bonds of respect and understanding among the many different strata represented by its participants. Scholars from different countries and different disciplines developed new ways to work together in the future. Both natives and community people interacted with scholars (and watched them interact with each other), and gained a better understanding of how scholars think and how they approach their work. Native peoples began to realize that their own points of view were respected, both by scholars and by foreigners. Scholars and foreigners realized that the community within which they were temporary guests supported not only their presence but also the goals and means of their work. Natives from different, isolated communities saw that although each tradition was unique, the experience of maintaining traditional heritage in the face of a dominant culture was the same. Finally, all saw the creative results of good field research -- the lasting bond of respect between academic researcher and native informant, when each realizes that $s /$ he has something of value to give the other.

On the final day of the workshop, participants discussed plans for future activities to be sponsored by the Society and the Program. 